\title{
Metabolic Effects of Exogenous Glucocorticoids in Fasted Man
}

\author{
O. E. Owen and G. F. Cahul, Jr. \\ From the Department of Medicine, Harvard Medical School, the Peter Bent \\ Brigham Hospital, and the Joslin Diabetes Foundation, Inc., Boston, \\ Massachusetts, 02215, and the Department of Medicine, Temple University \\ School of Medicine, Philadelphia, Pennsylvania 19104
}

A в S T R A C T The influence of administering excessive amounts of glucocorticoids on circulating substrates and hormones and on urinary excretion of nitrogenous compounds and ketone bodies was examined in man after prolonged starvation.

After 35 days of total caloric deprivation the administration of high physiologic doses of glucocorticoids increased circulating glucose and insulin levels without intensifying total urinary nitrogen excretion. The increased blood glucose seemed to be due to diminished peripheral uptake rather than augmented gluconeogenesis. A small, transient increase in circulating plasma amino acids was observed. However, the secondary rise in serum insulin seemed to block the proteolytic effect(s) of glucocorticoids, preventing them from mobilizing body protein stores during starvation. There was no change in circulating free fatty acids or glycerol. Thus, it appeared that the potential catabolic action of excessive glucocorticoids was offset by the anabolic effect of insulin, and a new state of homeostasis was established.

An additional effect of glucocorticoid administration was a marked diminution of renal excretion of ketone bodies.

\section{INTRODUCTION}

A metabolic steady state develops in humans after prolonged starvation and the body processes are comparable on a day-to-day basis $(1,2)$. Previous studies have shown that this steady state provides an ideal condition for investigating the acute metabolic effects of exogenously administered hormones (3-5). We took advantage of this steady state to investigate changes induced by glucocorticoid administration on circulating substrates

Dr. Owen is a George Morris Piersol Teaching and Research Scholar, American College of Physicians.

Received for publication 1 August 1972 and in revised form 21 May 1973. and hormones as well as on the urinary excretion of nitrogenous compounds and ketone bodies.

\section{METHODS}

Subjects. Six obese volunteers were admitted to the Clinical Research Center of the Peter Bent Brigham Hospital to study the metabolic effects of glucocorticoid administration (Table I). Each subject was informed of the potential risks involved in both starvation and exogenous glucocorticoid administration before admission. During the prestarvation period all subjects were screened to exclude cardiopulmonary, renal, hepatic, and endocrine abnormalities, as previously described (2).

During the prestarvation period of 4 or more days, subjects were fed about $2400 \mathrm{kcal} / \mathrm{day}$, consisting of $300 \mathrm{~g}$ carbohydrate, $100 \mathrm{~g}$ protein, and $85 \mathrm{~g}$ fat. The method of performing intravenous glucose tolerance has been described (2).

Daily intake during starvation consisted of one multivitamin capsule (Unicap, The Upjohn Co., Kalamazoo, Mich.), 17 meq of $\mathrm{NaCl}$ (sugar-free tablets), $1500 \mathrm{ml}$ of water, and, as tolerated, $13 \mathrm{meq}$ of $\mathrm{KCl}$ (gelatin capsule).

Blood and urine collections. Blood samples were obtained from the antecubital veins at 7:00 a.m. before the subject arose from bed as follows: 3 days prestarvation, on the day after an overnight fast (day 0 ), on days $3,10,14,21$, $28,31,34$, and 35 before glucocorticoid administration, and every day or two during glucocorticoid administration. During the fast and after glucocorticoid administration, additional blood samples were obtained from subjects A. B. R. S., and D. D. All blood samples were analyzed for glucose, $\alpha$-amino nitrogen, glycerol, acetoacetate, beta-hydroxybutyrate ( $\beta$-OH-butyrate), free fatty acids (FFA), ${ }^{1}$ immunoreactive insulin (IRI), and growth hormone (HGH) by methods previously published $(2,6-8)$.

$100 \mathrm{mg}$ cortisone acetate was given intramuscularly immediately after blood was drawn and then at 12-h intervals for 6 days. Thus, the blood samples obtained on day 35 of the fast were drawn just before the glucocorticoids were given, and the blood samples obtained on days 36-41 were obtained $12 \mathrm{~h}$ after the previous or final dose of cortisone. An exception is C. R., in whom the blood sample obtained on day 35 represents a preinfusion specimen, and

\footnotetext{
${ }^{1}$ Abbreviations used in this paper: FFA, free fatty acids; $\mathrm{HGH}$, human growth hormone; IRI, immunoreactive insulin.
} 
TABLE I

Clinical Data

\begin{tabular}{|c|c|c|c|c|c|c|c|c|c|}
\hline \multirow[b]{3}{*}{ Subject } & \multirow[b]{3}{*}{ Age } & \multirow[b]{3}{*}{ Sex } & \multirow[b]{3}{*}{ Height } & \multirow{2}{*}{\multicolumn{2}{|c|}{ Weight }} & \multirow{3}{*}{$\begin{array}{l}\text { i.v. } \\
\text { GTT* }\end{array}$} & \multicolumn{3}{|c|}{ Starvation } \\
\hline & & & & & & & \multirow{2}{*}{$\begin{array}{l}\text { Con- } \\
\text { trol }\end{array}$} & \multirow{2}{*}{$\begin{array}{l}\text { Glucocorticoid } \\
\text { administration }\end{array}$} & \multirow{2}{*}{$\begin{array}{l}\text { Follow- } \\
\text { up }\end{array}$} \\
\hline & & & & Initial & Final & & & & \\
\hline & $y r$ & & $\mathrm{~cm}$ & $k g$ & $\mathrm{~kg}$ & $K_{0}$ & & Days of sludy $\ddagger$ & \\
\hline P. C. & 32 & M & 170.8 & 169.0 & 148.1 & 1.4 & $0-35$ & $35-36$ & - \\
\hline S. C. & 33 & $\mathrm{~F}$ & 163.0 & 117.0 & 101.7 & 0.7 & $0-35$ & $35-40$ & - \\
\hline A. B. & 19 & M & 180.3 & 154.0 & 126.6 & 1.2 & $0-35$ & $35-40$ & $41-44$ \\
\hline R. S. & 21 & M & 180.0 & 160.6 & 130.8 & 1.4 & $0-35$ & $35-40$ & $41-49$ \\
\hline D. D. & 20 & $\mathrm{~F}$ & 159.0 & 108.9 & 87.3 & 1.7 & $0-35$ & $35-40$ & $41-55$ \\
\hline C. R. & 16 & $\mathrm{~F}$ & 167.6 & 104.1 & 85.6 & 2.1 & $0-35$ & $35-38$ & $38-47$ \\
\hline
\end{tabular}

* Intravenous glucose tolerance test $(0.5 \mathrm{~g} / \mathrm{kg})$ performed before weight reduction. Values expressed as absolute per cent disappearance per minute.

$\ddagger$ After an overnight fast, day 0 , all subjects underwent total caloric starvation. After blood and urine collections were completed on the 35 th morning administration of glucocorticoids was started. C. R. received hydrocortisone sodium hemisuccinate i.v. while all other subjects were given cortisone acetate i.m.

blood drawn on days 36,37 , and 38 represents 24,48 , and 72-h specimens, respectively, obtained during the continuous intravenous infusion of $200 \mathrm{mg} /$ day hydrocortisone sodium hemisuccinate. Additional blood specimens were obtained on days 35 through 38 from $\mathrm{C}$. R. to determine plasma cortisol concentration by the double isotope derivative technique (9) and free plasma amino acids as previously described (10).

Urine was collected in refrigerated plastic containers for 24-h periods beginning immediately after the 7:00 a.m. blood specimens were obtained. The volumes were measured, and aliquots were frozen at $-20^{\circ} \mathrm{C}$ until analyses of total nitrogen, urea nitrogen, uric acid, creatinine, ammonium, acetoacetate, and $\beta$-OH-butyrate were completed. Methods used for determining these urine substances have been published $(2,6)$. Urinary 17 -hydroxycorticoids were determined as Porter-Silber chromogens (11), and urinary 17-ketosteroids were measured by the Zimmerman test (12). Day 0-day 1 designates the first 24-h urinary specimen initiated after an overnight fast. For those subjects who received cortiscne acetate, the urine specimens designated as days 35 through 40 represent those obtained during glucocorticoid administration. The urine specimens obtained from $C$. R. for days 35 through 37 represent those collected during the 72 -h continuous intravenous hydrocortisone infusion period.

Statistical analyses. The paired $t$ test and the coefficient of correlation were employed to determine statistical significance (13).

\section{RESULTS}

After a latent period of several hours all subjects given intramuscular cortisone acetate complained of mild persistent pain at the injection site. No other adverse symptoms developed.

The morning concentrations of circulating glucose, insulin, $\beta-\mathrm{OH}$-butyrate, and acetoacetate throughout the prestarvation and starvation periods before, during, and after intramuscular administration of cortisone acetate to the five subjects are shown in Fig. 1. During the pre-

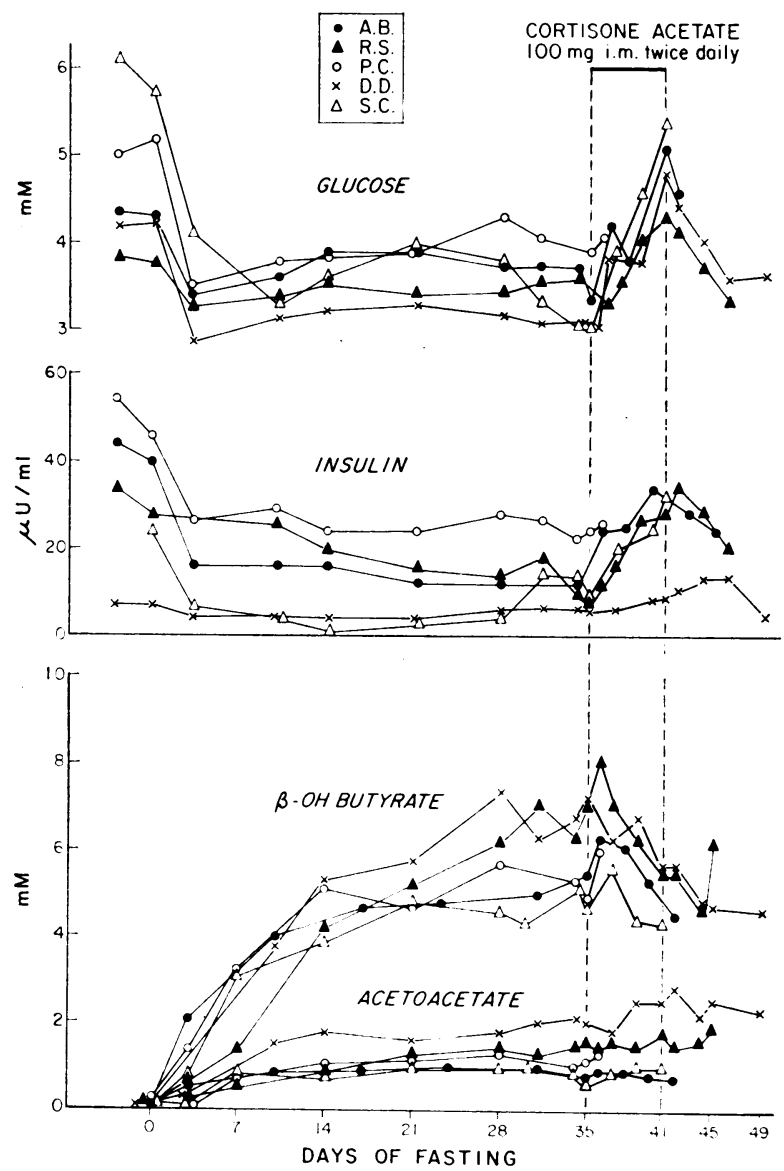

FIGURE 1 Individual values for circulating glucose, insulin, $\beta-\mathrm{OH}$ butyrate, and acetoacetate before and during starvation before, during, and after intramuscular cortisone administration. Blood samples obtained on days $36-41$ are those obtained $12 \mathrm{~h}$ after the previous dose of cortisone. 
TABLE 11

Influence of Cortisone Administration on Ciroulating Hormonal and Substrate Coneentrations during Prolonged Starvation*

\begin{tabular}{|c|c|c|c|c|}
\hline \multirow[b]{2}{*}{ Experimental period day of fast } & \multirow{2}{*}{$\frac{\text { Precortisone }}{35}$} & \multicolumn{3}{|c|}{ Cortisone acetate administration } \\
\hline & & $36-37$ & 39 & $41-42$ \\
\hline Serum insulin, $\mu U / m l$ & $8 \pm 3$ & $14 \pm 5$ & $20 \pm 5 \ddagger$ & $27 \pm 6 \ddagger$ \\
\hline Serum growth hormone, $\mathrm{ng} / \mathrm{ml}$ & $0.6 \pm 0.7$ & $1.3 \pm 0.9$ & $0.4 \pm 0.2$ & $0.4 \pm 0.2$ \\
\hline Blood glucose, $\mathrm{mmol} / \mathrm{liter}$ & $3.20 \pm 0.09$ & $3.78 \pm 0.22$ & $4.18 \pm 0.17 \ddagger$ & $4.88 \pm 0.23 \ddagger$ \\
\hline Plasma free fatty acids, $\mathrm{mmol} /$ liter & $1.28 \pm 0.16$ & $1.36 \pm 0.09$ & $1.33 \pm 0.08$ & $1.24 \pm 0.07$ \\
\hline Blood glycerol, $\mathrm{mmol} /$ liter & $0.108 \pm 0.028$ & $0.092 \pm 0.012$ & $0.087 \pm 0.009$ & $0.085 \pm 0.012$ \\
\hline Blood $\beta$-OH-butyrate, $\mathrm{mmol} /$ liter & $6.12 \pm 0.61$ & $6.54 \pm 0.55$ & $5.91 \pm 0.53$ & $4.95 \pm 0.05 \ddagger$ \\
\hline Blood acetoacetate, mmol/liter & $1.20 \pm 0.35$ & $1.30 \pm 0.25$ & $1.48 \pm 0.36$ & $1.52 \pm 0.38 \ddagger$ \\
\hline Serum $\alpha$-amino nitrogen, $\mathrm{mmol} /$ liter & $3.90 \pm 0.28$ & $3.63 \pm 0.16$ & $3.81 \pm 0.11$ & $3.76 \pm 0.26$ \\
\hline
\end{tabular}

* Data presented as mean \pm SEM. Data from subject P. C. is omitted since blood was obtained only on days 35 and 36.

$\ddagger$ Probability that concentration change is statistically significantly different $(P<0.05)$ from precortisone period (paired $t$ test).

cortisone starvation period each subject had the characteristic fall in blood glucose and serum insulin with the subsequent elevation of plasma FFA and blood $\beta-\mathrm{OH}$ butyrate and acetoacetate. 6 days of cortisone acetate administration increased glucose and insulin concentrations in all subjects, including S. C., who had latent
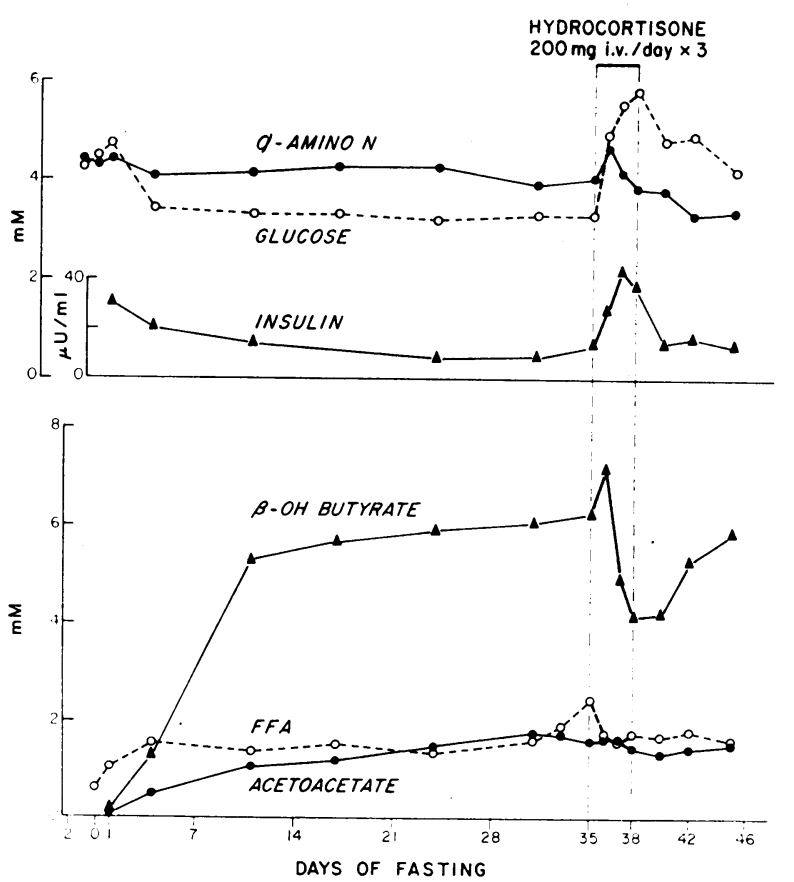

FIGURE 2 Concentrations of circulating $\alpha$-amino nitrogen $(\mathrm{N})$, glucose, insulin, $\beta-\mathrm{OH}$ butyrate, acetoacetate, and FFA in one subject (C. R.) before and during starvation, including the 72 -h period of intravenous hydrocortisone infusion. Blood samples taken on days 36,37 , and 38 represent 24,48 , and $72-h$ specimens, respectively, obtained during the continuous infusion. cliabetes mellitus. The direct relationship of glycemia and insulinemia before, during, and after cortisone administration is displayed.

Table II presents the results of all measured circulating substrates and hormones during the precortisone and cortisone administration periods. Blood glucose and serum IRI levels increased significantly $(P<0.05)$ during cortisone treatment when compared with the precortisone control period. The mean peak values were detected after the last dose of cortisone acetate was administered. Although the rise in serum insulin lagged behind the glucose response in subjects R. S. and D. D., the mean peak value coincided with that of glucose. The apparent early rise in $\beta$-OH-butyrate after cortisone administration is not statistically significant $(P>0.05)$. However, the fall in blood $\beta-\mathrm{OH}$-butyrate and rise in blood acetoacetate by day 41 or 42 in the four subjects who received the 6-day course of cortisone administration were significantly different $(P<0.05)$ from the day 35 values. The total blood ketone body (acetoacetate plus $\beta$-OH-butyrate) concentration at day 35 of $7.32 \pm$ $0.95 \mathrm{mmol} / \mathrm{liter}$ was similar to the concentration at day (s) $41-42$ of $6.47 \pm 0.83 \mathrm{mmol} /$ liter. The intramuscular administration of cortisone did not alter the prolonged fasting steady state concentrations of circulating FFA, glycerol, or $\alpha$-amino nitrogen. Transient changes could have been missed. HGH concentrations, obtained only at 7:00 a.m. before the subjects arose remained low, less than $1.10 \mathrm{ng} / \mathrm{ml}$, before and after glucocorticoid administration.

The effect of the slow absorption of cortisone acetate from the intramuscular depot was eliminated by administering biologically equivalent amounts of hydrocortisone intravenously to one subject, C. R. The circulating insulin and substrate responses to the constant $72-\mathrm{h}$ infu- 
sion of $200 \mathrm{mg} /$ day of hydrocortisone sodium hemisuccinate are shown in Fig. 2. The baseline blood glucose concentration of $3.39 \mathrm{mmol} /$ liter $(61 \mathrm{mg} / 100 \mathrm{ml})$ progressively rose during the infusion to $5.76 \mathrm{mmol} / \mathrm{liter}$ $(104 \mathrm{mg} / 100 \mathrm{ml})$, an increase of $70 \%$. Serum insulin concentrations tended to parallel the glucose increase, rising from a baseline value of $12 \mu \mathrm{U} / \mathrm{ml}$ to $44 \mu \mathrm{U} / \mathrm{ml}$ at $48 \mathrm{~h}$ and $38 \mu \mathrm{U} / \mathrm{ml}$ at $72 \mathrm{~h}$ of infusion. $\beta$-OH-butyrate showed an apparent increase from a baseline concentration of 6.24 to $7.20 \mathrm{mmol} / \mathrm{liter}$ at the 24 -h blood-sampling interval, then fell to $4.16 \mathrm{mmol} / \mathrm{liter}$ after $72 \mathrm{~h}$ of infusion. Several days after the infusion, circulating glucose, insulin, and $\beta-\mathrm{OH}$-butyrate approached preinfusion fasting values. There was no significant response in plasma FFA or blood acetoacetate to the infused hydrocortisone. Not shown are the glycerol values, which remained constant throughout the preinfusion, infusion, and postinfusion periods. The hydrocortisone infusion elevated the baseline $\alpha$-amino nitrogen from 4.00 to $4.65 \mathrm{mmol} /$ liter at the 24-h interval, and then progressively depressed the levels to a minimal concentration of $3.30 \mathrm{mmol} /$ liter on day 42, the fourth postinfusion day. Plasma free amino acids during fasting were measured in subject C. R. before and during the hydrocortisone infusion periods (Table III). The changes in amino acid concentrations verify the fluctuations in plasma $\alpha$-amino nitrogen. Taurine, aspartic acid, threonine, serine, proline, glycine, alanine, $\alpha$-amino- $N$-butyric acid, valine, and leucine are initially increased and subsequently depressed to baseline values. None of the amino acids declined

TABLE III

Influence of 72-h Hydrocortisone Infusion in One Subject

(C. R.) upon Individual Plasma Free Amino Acids during Prolonged Starvation

\begin{tabular}{|c|c|c|c|c|}
\hline Amino acid & $\begin{array}{l}\text { Base- } \\
\text { line* }\end{array}$ & $24-\mathrm{h}$ & 48-h & $72-\mathrm{h}$ \\
\hline & \multicolumn{4}{|c|}{$\mu .1 I$} \\
\hline Taurine & 46 & 103 & 80 & 60 \\
\hline Aspartic acid & 13 & 16 & 23 & 17 \\
\hline Threonine & 297 & 318 & 304 & 29.3 \\
\hline Serine & 158 & 180 & 161 & 154 \\
\hline Proline & 169 & 212 & 194 & 167 \\
\hline Citrulline & 16 & 1.3 & 15 & 18 \\
\hline Glycine & 478 & 521 & 418 & 3.54 \\
\hline Alanine & 122 & 1.57 & 1.39 & 125 \\
\hline$\alpha$-Amino- $N$-butyric acid & 33 & 51 & 47 & 45 \\
\hline Valine & 1.36 & 194 & 187 & 1.56 \\
\hline Methionine & 20 & 28 & 32 & 30 \\
\hline Isoleucine & 59 & 80 & 77 & 72 \\
\hline Leucine & 94 & 141 & 12.3 & 109 \\
\hline Tyrosine & 49 & 55 & 59 & 59 \\
\hline Phenylalanine & 50 & 68 & 71 & 66 \\
\hline Ornithine & - & 38 & 34 & 47 \\
\hline Lysine & - & $7 i$ & 79 & 7.3 \\
\hline Arginine & -- & 78 & 100 & 79 \\
\hline
\end{tabular}

* Baseline values are concentrations of individual amino acids immediately. before beginning the $72-\mathrm{h}$ constant infusion.

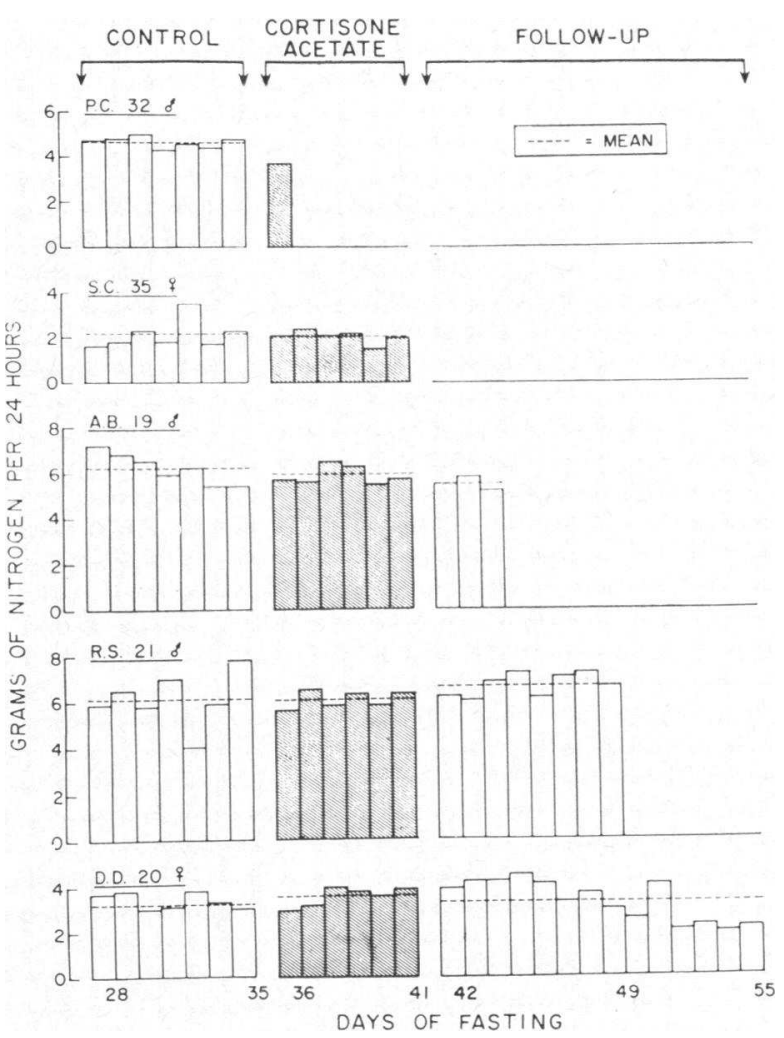

Figure 3 Individual values for total nitrogen excretion in subjects before, during, and after intramuscular injection of $100 \mathrm{mg}$ of cortisone acetate twice daily. The dashed horizontal lines represent the mean values in each subject for each experimental period.

below baseline values during the infusion period. Thus, during the $72-\mathrm{h}$ infusion period both plasma $\alpha$-amino nitrogen and free amino acids transiently increased and then decreased to near preinfusion concentrations. More acute effects of the steroid on amino acid concentrations were not directly examined.

The influence of $200 \mathrm{mg}$ daily of cortisone acetate administered intramuscularly after 35 days of fasting on 24-h urinary total nitrogen excretion is shown in Fig. 3. There was no significant change in the total urinary nitrogen loss. However, there are shifts in the proportion of urea and ammonium. Urinary urea and ammonium nitrogen before, during, and after cortisone administration is shown in Fig. 4. The apparent increase in nitrogen excretion (urea plus ammonium) after the cessation of cortisone administration is not real (Fig. 4). It is due to the fact that total and fractional urinary nitrogenous excretory rates were measured in only three subjects (A. B., R. S., and D. D.). Two of these subjects, A. B. and R. S., had large excretory rates. The importance of continuous monitoring during the postcortisone period was not obvious when the studies were initiated. Urea excretion diminishes progressively dur- 


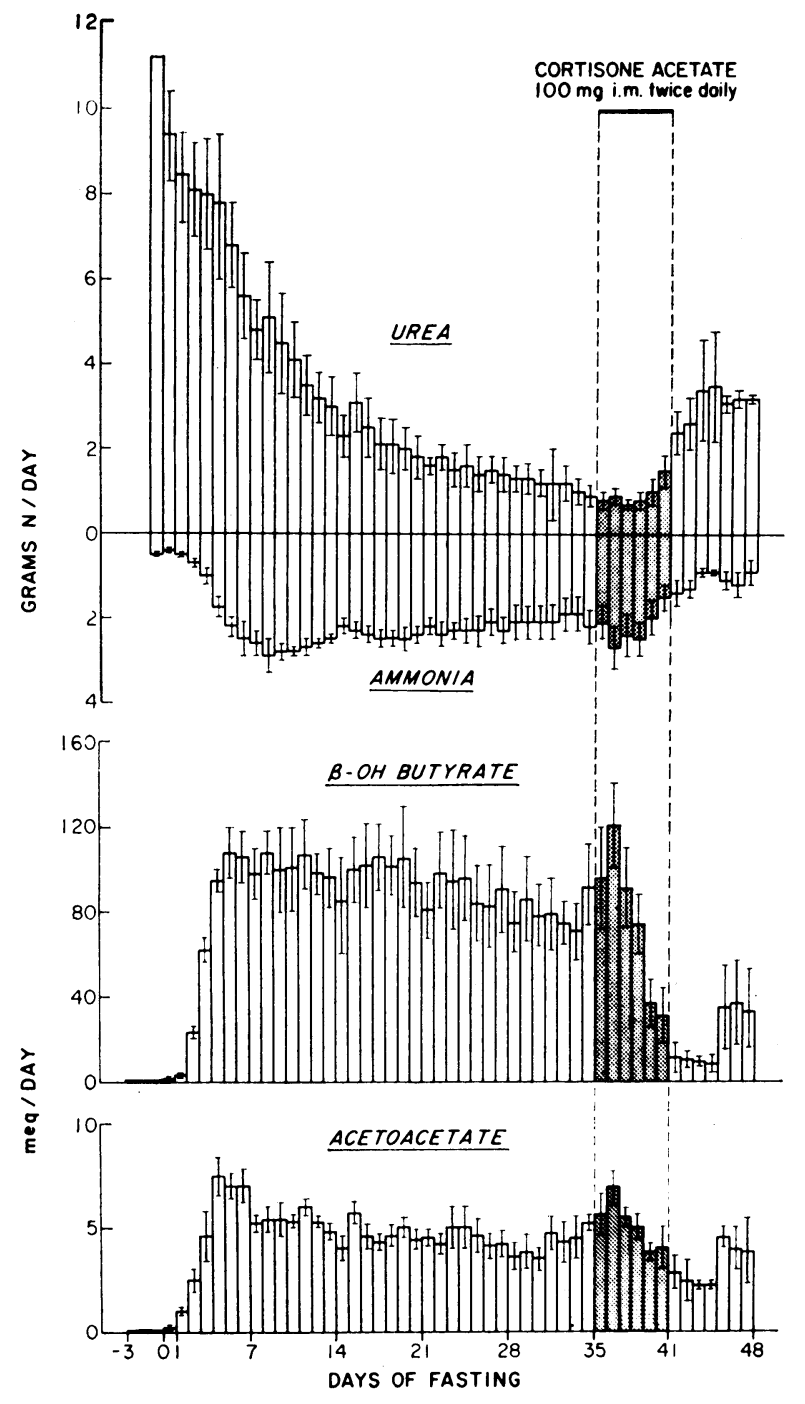

Figure 4 Excretion of urea and ammonia nitrogen and keto acids after i.m. cortisone in prolonged fasting. The length of the bars represents the mean values for five subjects during the presteroid cortisone periods and three subjects during the poststeroid period.

ing the first 4 wk of fasting, after which it remains fairly constant. Ammonium excretion reaches a maximum after about 1 wk of fasting, then plateaus, and becomes equal to or greater than urea excretion. The initial effect of intramuscular cortisone was an increase and subsequent decrease in ammonium excretion. In contrast to ammonium excretion there are reciprocal changes in urea excretion with a progressive and significant $(P<$ 0.05 ) twofold increase in urea excretion noted by day 42. The oppositely directed effects of cortisone during prolonged starvation on ammonium and urea excretion canceled any net change in total urinary nitrogen. Not shown is the difference between urinary total nitrogen excretion and ammonium plus urea nitrogen excretion, which is comprised of creatinine, uric acid, amino acids, and other nitrogenous compounds. The sum of these urinary compounds also did not change significantly with cortisone administration.

Similar directional changes were obtained after administering hydrocortisone intravenously for $72 \mathrm{~h}$ to subject C. R. The maximal effects of hydrocortisone on urea and ammonium excretion were manifested 3-4 days after infusion. The results are presented in Fig. 5.

The fluctuation in urinary ammonium excretion before, during, and after cortisone administration are paralleled by changes in urinary $\beta$-OH-butyrate and acetoacetate excretion $(r=0.8, P<0.01)$. There was a transient increase and a subsequent decrease in ketonuria. In one subject, C. R., intravenous hydrocortisone appeared to dissociate ketonuria temporarily from ammonium excretion. The maximal alterations in urinary excretions of urea, ammonium, $\beta$-OH-butyrate, and acetoacetate were present 3-4 days after cessation of cortisone or hydrocortisone administration. Data are presented in Fig. 4, 5, and 6.

Another point worthy of notation is that glucocorticoids'transiently diminished renal excretion of ketone bodies (Figs. 4 and 6 ). This is most obvious several days after the cessation of glucocorticoids, when the blood concentrations of acetoacetate and $\beta$-OH-butyrate were approximately equal to the presteroid control period (Figs. 1 and 2).

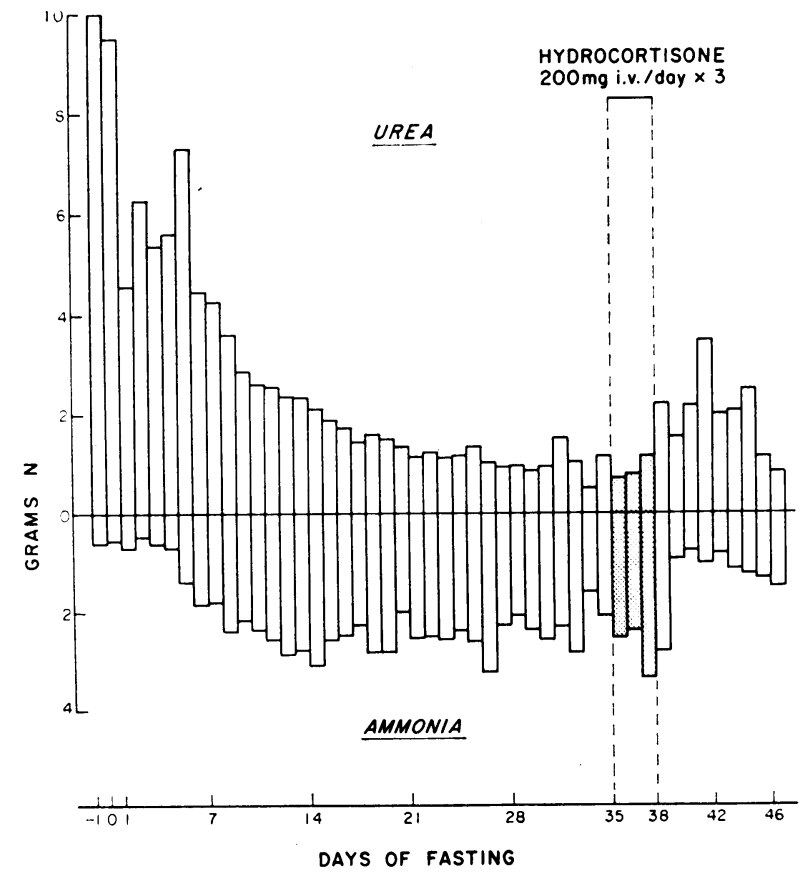

Figure 5 Influence of intravenous hydrocortisone on urinary excretion of urea and ammonium nitrogen in one subject (C. R.). 


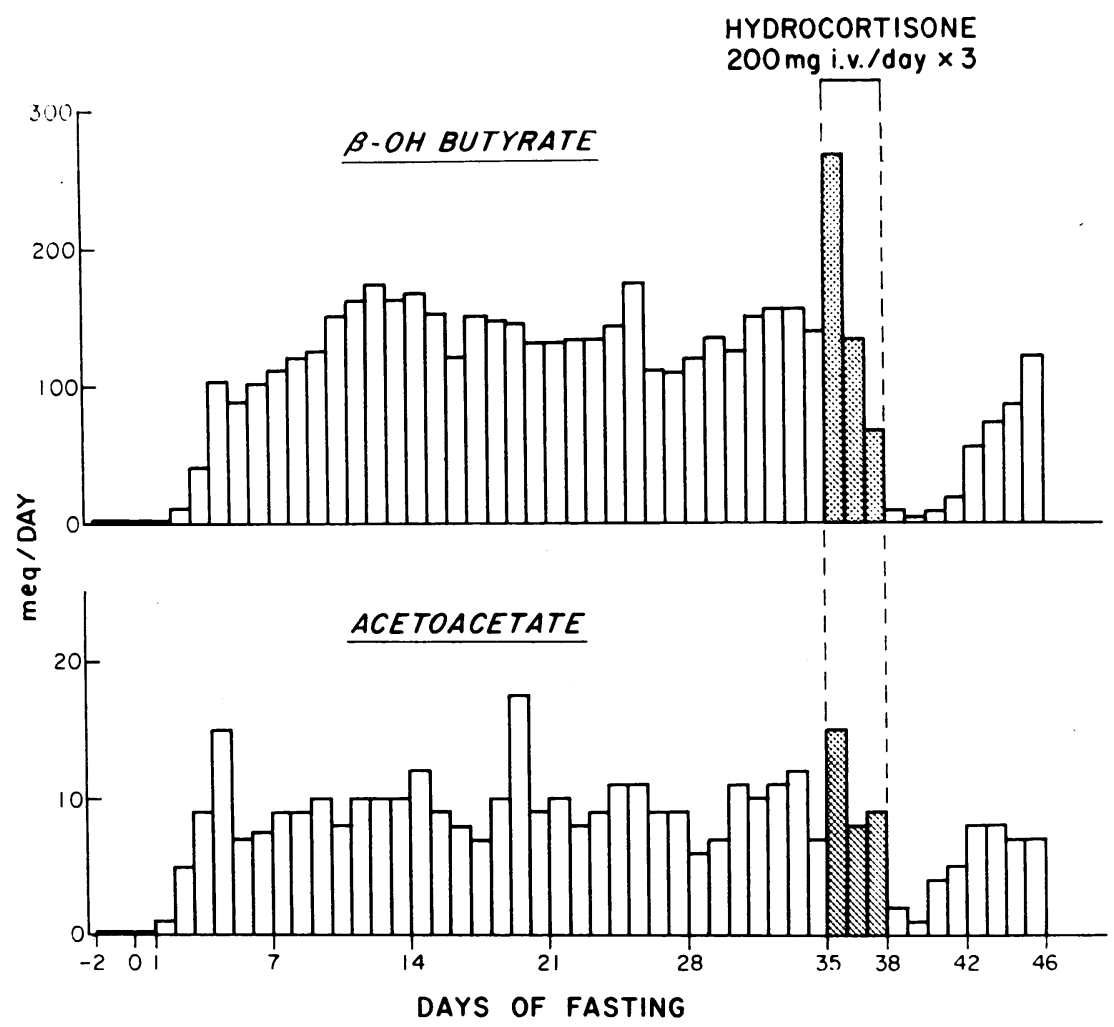

FIGURE 6 Effect of intravenous hydrocortisone on urinary excretion of $\beta$-OH-butyrate and acetoacetate in one subject (C. R.).

The influence of intramuscular cortisone acetate 100 mg every $12 \mathrm{~h}$, starting on the 35th morning and stopping on the 40th evening, on urinary excretion of 17-hydroxycorticosteroids is presented in Table IV. The low 24-h urinary excretion rates for 17-hydroxy-corticosteroids during the starvation precortisone period are consistent with previously reported data (14). Delayed absorption or excretion of the exogenous administered cortisone or both is obvious. Increased excretion persisted during the postcortisone period for as long as urine was assayed for 17-hydroxy-corticosteroid content. The influences of infusion of $200 \mathrm{mg}$ hydrocortisone hemisuccinate daily, starting on the 35th morning and stopping on the 38th morning, in one subject, C. R., on urinary $17-$ hydroxy-corticosteroid excretion rates and plasma cortisol concentrations are shown in Table V. During the

TABLE IV

Daily Urinary Excretion of 17-Hydroxycorticoids*

\begin{tabular}{|c|c|c|c|c|c|c|c|c|c|c|c|c|c|c|c|c|}
\hline \multirow{2}{*}{$\frac{\text { Experimental period }}{\text { Day of fast }}$} & \multicolumn{2}{|c|}{ Precortisone } & \multicolumn{6}{|c|}{ Cortisone administration } & \multicolumn{8}{|c|}{ Postcortisone } \\
\hline & 33 & 34 & 35 & 36 & 37 & 38 & 39 & $40 \ddagger$ & 41 & 42 & 43 & 44 & 45 & 46 & 47 & 48 \\
\hline \multicolumn{17}{|c|}{$m g / 24 h$} \\
\hline P. C. & 7 & 6 & 8 & - & - & - & - & - & - & - & - & - & - & - & - & - \\
\hline S. C. & 1 & 7 & 3 & 0 & - & - & 9 & 10 & 8 & - & - & - & - & - & - & - \\
\hline A. B. & 6 & 6 & 9 & 8 & 13 & 15 & 17 & 21 & 20 & 18 & 16 & - & - & - & - & - \\
\hline R. S. & 5 & 9 & 9 & 13 & 14 & 18 & 15 & 27 & 19 & 17 & 19 & 18 & 14 & 14 & 16 & 16 \\
\hline D. D. & 12 & 3 & 2 & 7 & 2 & 4 & 7 & 44 & 23 & 18 & 15 & 15 & $\ldots$ & 15 & 13 & 16 \\
\hline
\end{tabular}

* The data show the changes in urinary excretion rates of 17 -hydroxycorticoids before, during, and after intramuscular injection of $100 \mathrm{mg}$ of cortisone acetate twice daily to five obese subjects undergoing prolonged starvation.

‡ Urinary collections started at 7:00 a.m. on day noted and continued until 7:00 a.m. the next day. Thus day 40 terminated on day 41 . 
TABLE $\mathrm{V}$

Circulating Hydrocortisone and Daily Urinary Excretion of 17-Hydroxycorticoids

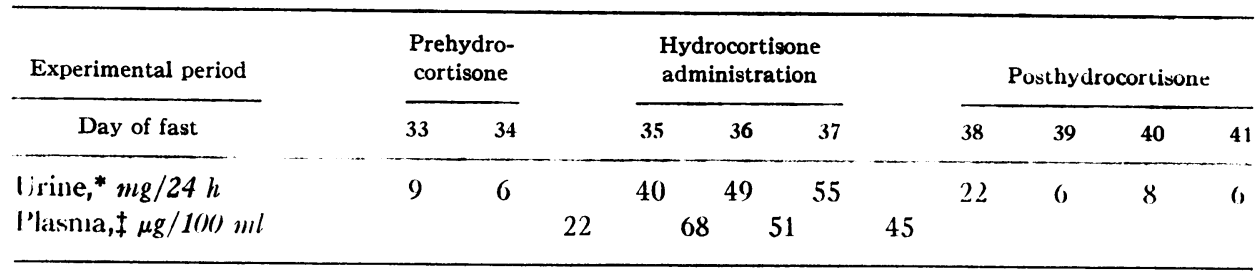

* Urinary collections began at 7:00 a.m. on the day_noted and continued until 7:00 a.m. the next day.

$\ddagger$ The blood sample for determining baseline plasma hydrocortisone level was drawn on the 35th morning just before starting the intravenous hydrocortisone sodium hemisuccinate infusion of $200 \mathrm{mg}$ daily.

first $24 \mathrm{~h}$ after infusion of hydrocortisone, urinary excretion of 17-hydroxy-corticosteroids increased severalfold and remained elevated throughout the 72-h infusion period and first 24-h postinfusion period. Similarly changes in plasma cortisol levels are reported for the 72 - $h$ infusion period. The normal plasma cortisol concentration after 35 days of starvation and before hydrocortisone infusion is consistent with a previous report that circulating concentrations of cortisol are not depressed by fasting (15). From 24 to $48 \mathrm{~h}$ after infusion urinary 17 -hydroxy-corticosteroids returned to preinfusion values.

\section{DISCUSSION}

There is a sparsity of reports describing predictable metabolic responses of humans to exogenously administered glucocorticoids. The present study gives information on the influence of large doses of glucocorticoids on circulating substrate and hormone concentrations, urinary nitrogenous products, and ketone-body excretory rates in humans. Here an attempt is made to integrate the relationships anong glucocorticoids, insulin, and substrate metabolism.

It has been well established from in vitro preparations that the unopposed actions of glucocorticoids result in selected protein catabolism (16-18), inhibited protein synthesis (19-22), increased amino acid mobilization (23), and increased hepatic gluconeogenesis appropriately accompanied by increased amino acid-metabolizing enzymes (24-26). Data obtained from intact animals and humans are not so definitive. If glucocorticoids are able to induce net protein catabolism with amino acid mobilization and hypergluconeogenesis, an increased urinary excretion of nitrogen would be expected. Data pertaining to nitrogen balance in humans subjected to excessive amounts of glucocorticoids have failed to support this pattern.

In 1943 Albright reported that the "nitrogen minimum excretion (i.e., nitrogen excretion on a high-caloric, low-protein intake)" in two patients with Cushing's syndrome was no more than that observed in normal man (27). Parson, Crispell, and Ebbert, in their studies using $\left[{ }^{15} \mathrm{~N}\right]$ glycine in ACTH-treated normal man, found only a minimal and transient negative nitrogen balance in two or three experiments (28). However, there was a striking alteration in the metabolism of glycine, in that a large fraction of this amino acid was converted into urea and excreted in the urine. Conversely, a smaller fraction was available for synthetic processes. Eliel and Heaney observed a patient, maintained on an isocaloric, zero-amino acid intake, whose urinary nitrogen excretion stabilized at about $2.0 \mathrm{~g} /$ day. With subsequent administration of $200-600 \mathrm{mg}$ of cortisone acetate daily there was a transient increase in nitrogen excretion of only $0.1 \mathrm{~g} /$ day (29). We did not observe a significant increase in total urinary nitrogen excretion after giving glucocorticoids. There was a decrease in ammonium excretion with a concomitant increase in urea excretion, suggesting a partial shift from renal to hepatic gluconeogenesis (2). These oppositely directed effects on urea and ammonium excretion negate a net change in gluconeogenesis from amino acids. Furthermore, since urinary nitrogen excretion is a reliable index of protein breakdown in subjects fasting for prolonged periods (30), the failure to demonstrate an increase in total urinary nitrogen excretion after the administration of glucocorticoids to fasting man suggests that the catabolic effects of these hormones during a state of fasting were absent or minimal.

After administering glucocorticoids, elevated or depressed concentrations of circulating amino acids or both have been reported in both animal and human experiments (31-35). Previous studies suggested that these differences appear to be time-related (36). The intravenous infusion of hydrocortisone resulted in a transient elevation and subsequent decline of plasma $\alpha$-amino nitrogen as well as in individual amino acids. The initial elevation induced by glucocorticoids is con- 
sistent with an increase in amino acid mobilization from the peripheral tissues (37). A feasible explanation for the subsequent depression is the decreased release of amino acids from muscle (the body's principal protein store) coincident with the secondary hyperinsulinemia (38) that developed after glucocorticoid administration. It is unlikely that the decline was due to an increased net removal of amino acids by the liver and kidney since urea plus ammonium nitrogen excreted did not increase. Furthermore, glucocorticoid-induced hyperaminoaciduria as a means of elimination of significant quantities of nitrogen $(35,39)$, is improbable since there was no substantial change in renal excretion of "unmeasured" urinary nitrogen. It appears that the potential catabolic action of excessive glucocorticoids was offset by the anabolic effect of insulin, and a new state of homeostasis was established. A possibility is that glucocorticoids may have enhanced synthesis of specific proteins, at the expense of other catabolized proteins. Such action(s) could shift the protein mass of different organs without affecting total body nitrogen balance. The data from this study do not allow assessment of this possibility.

The hyperglycemia that develops after the administration of glucocorticoids may reflect altered rates of gluconeogenesis, peripheral glucose utilization, any combination of the two, or unaltered rates with merely a changed concentration in substrate. Long, Katzin, and Fry reported in 1940 that treating normal rats with cortical extract increased the amount of glucose present in the blood and tissue fluids. Concurrently, there was no change in oxygen consumption, indicating that total calories consumed remain constant. There was a decrease in the respiratory quotient showing a shift in the source of energy from carbohydrate to fat (40). Thorn, Koepf, Lewis, and Olsen reported that in patients with Addison's disease, glucocorticoids increased the fasted blood glucose concentration, decreased the respiratory quotient, and normalized the basal metabolic requirement (41). Subsequent investigators showed that physiological concentrations of glucocorticoids decreased glucose uptake in animal adipose tissue, muscle, lymphoid tissue, and skin $(25,42,43)$. Thus, the hyperglycemia induced by glucocorticoids is due, at least in part, to diminished peripheral uptake. However, the influence of glucocorticoids on carbohydrate consumption appears to be small and transient.

In this study, the urinary nitrogen excretion did not increase after glucocorticoid administration. This suggests that the fasting hyperglycenia was due to a resetting of the glucose-insulin relationship rather than to increased gluconeogenesis. After a fast of 3 or more days, peripheral tissues of man, mainly muscle and adipose tissue, derive about $10 \%$ of their substrate re- quirements from glucose oxidation (44). This amounts to approximately $10 \mathrm{~g}$ of glucose oxidized/day by peripheral tissues. We can assume that these obese starved subjects (see Table I) have a glucose space of about $15 \%$ of their body weight (45) or 18 liters, and that blood glucose equals the glucose concentration throughout the free glucose pool. The increase in blood glucose from day 35 , precortisone, to days $41-42$, cortisone acetate administration, of $1.68 \mathrm{mmol} /$ liter (see Table II) would equal an accumulation of only $5 \mathrm{~g}$ of glucose in its pool over the 6-7 day observation period. If the production of glucose remained constant, diminishing glucose oxidation by less than $1 \mathrm{~g} /$ day could account for the observed fasting hyperglycemia after glucocorticoid administration. Calculations of similar magnitude can be made for subject of C. R., who received intravenous hydrocortisone sodium hemisuccinate.

Glucocorticoids not only reduce glucose uptake by adipose tissue and play a permissive role in normalizing and/or potentiating the catecholamines and $\mathrm{HGH}$-induced release of FFA (46-49), but also possess a direct effect on mobilizing FFA from adipose tissue (50). However, their lipolytic effect can be overcome by insulin (50). Therefore, it is not surprising that the adipokinetic actions of glucocorticoids in animals or humans have been variously reported to progressively increase (51), transiently decrease (52), or to leave unchanged (53) the release of FFA from adipose tissue. Perhaps these differences are related to the evoked insulin responses. In this study there were no significant changes in the circulating concentrations of FFA or glycerol after administration of glucocorticoids. The potential adipokinetic effects of glucocorticoids could have been masked by the resulting hyperinsulinemia with its antilipolytic action. It is not disturbing to note that in these patients, the blood glucose levels rose while plasma FFA remained unchanged, since more insulin is required to promote translocation of glucose than is needed to block lipolysis $(54,55)$.

The ketogenic interplay between insulin and glucocorticoids deserve special consideration. The administration of glucocorticoids to animals or humans with coexisting diabetes mellitus and adrenal insufficiency showed intensification of ketonemia and ketonuria (5658). Kinsell et al. showed that the administration of ACTH accelerated the development and augmented the degree of ketoacidosis in a severely diabetic patient deprived of food and insulin (59). Additional insulin corrected the catabolic state induced by glucocorticoids. On the other hand, administering ACTH or cortisone to individuals without pre-existing endocrinopathies resulted in suppression of fasting-induced hyperketonemia and ketonuria (59). Sinilarly, Scott and Engel showed that in normal rats cortisone and hydrocortisone sup- 
pressed both fasting and cold stress ketosis (60). In essence, previous studies showed that glucocorticoids suppressed the development of fasting hyperketonemia and ketonuria if the pancreas was intact. In our study fasting hyperketonemia and ketonuria were well established before glucocorticoid administration. Intramuscular cortisone did not significantly change the total concentration of circulating ketone bodies, although a slight reduction in the $\beta$-OH-butyrate/acetoacetate ratio was observed. Since $\beta-\mathrm{OH}$-butyrate is the major ketone body present in the blood after prolonged starvation, it is possible that continuous administration may have significantly depressed circulating concentrations of ketone bodies. Administration of intravenous hydrocortisone in one subject suppressed blood $\beta$-OH-butyrate concentrations without significantly increasing blood acetoacetate concentrations and, therefore, depressed total ketonemia. This occurred while plasma FFA concentrations remained unchanged.

Increasing evidence indicates that hepatic production of ketone bodies is influenced by hormones as well as the supply of ketogenic precursors (61). The hyperinsulinemia we observed after glucocorticoid administration may have suppressed hepatic ketone body production without modifying the delivery of FFA to the liver (61).

\section{ACKNOWLEDGMENTS}

The authors wish to express their appreciation to Dzidra Rumba, Adacie Allen, Velta Ramolins, Wilma Lauris, and Anna Karras for their expert technical assistance, to the nurses and staff of the Clinical Center at the Peter Bent Brigham Hospital, and to Rachelle Masloff for her secretarial assistance. Amino acid analyses were kindly performed by Dr. T. T. Aoki.

This work was supported in part by U. S. Public Health Service NIH Grants AM-05077, AM-15191 and Grants FR-31 and RR 349, General Clinical Research Centers Branch, National Institutes of Health.

\section{REFERENCES}

1. Benedict, F. G. 1915. A Study of Prolonged Fasting. Carnegie Institution of Washington, Washington, D. C.

2. Owen, O. E., P. Felig, A. P. Morgan, J. Wahren, and G. F. Cahill, Jr. 1969. Liver and kidney metabolism during prolonged starvation. J. Clin. Invest. 48: 574.

3. Marliss, E. B., T. T. Aoki, R. H. Unger, J. S. Soeldner, and G. F. Cahill, Jr. 1970. Glucagon levels and metabolic effects in fasting man. J. Clin. Invest. 49: 2256.

4. Felig, P., E. B. Marliss, and G. F. Cahill, Jr. 1971. Metabolic response to human growth hormone during prolonged starvation. J. Clin. Invest. 50: 411.

5. Merimee, T. J., P. Felig, E. Marliss, S. E. Fineberg, and G. F. Cahill, Jr. 1971. Glucose and lipid homeostasis in the absence of human growth hormones. J. Clin. Invest. 50: 574.

6. Cahill, G. F., Jr., M. G. Herrera, A. P. Morgan, J. S. Soeldner, J. Steinke, P. L. Levy, G. A. Reichard, Jr., and D. M. Kipnis. 1966. Hormone-fuel interrelationships during fasting. J. Clin. Invest. 45: 1751.
7. Soeldner, J. S., and D. Slone. 1965. Critical variables in the radioimmunoassay of serum insulin using the double antibody technic. Diabetes. $14: 771$.

8. Boden, G., and J. S. Soeldner. 1967. A sensitive double antibody radioimmunoassay for human growth hormone $(\mathrm{HGH})$ : Levels of serum $\mathrm{HGH}$ following rapid tolbutamide infusion. Diabetologia. 3: 413.

9. Kliman, B., and R. E. Peterson. 1960. Double isotope derivative assay of aldosterone in biological extracts. J. Biol. Chem. 235 : 1639.

10. Felig, P., O. E. Owen, J. Wahren, and G. F. Cahill, Jr. 1969. Amino acid metabolism during prolonged starvation. J. Clin. Invest. 48 : 584.

11. Reddy, W. J., D. Jenkins, and G. W. Thorn. 1952. Estimation of 17-hydroxy-corticoids in urine. Metab. (Clin. Exp.). 1: 511 .

12. Peterson, R. E., and C. E. Pierce. 1960. Methodology of urinary 17 -ketosteroids. In Lipids and Steroid Hormones in Clinical Medicine. S. W. Saunderman and S. W. Sunder, editors. J. B. Lippincott Co., Philadelphia, Pa. 147.

13. Snedecor, G. W. 1956. Statistical Methods. Iowa State University Press, Ames, Iowa. 5th edition. 35.

14. Rapoport, A., G. L. A. From, and H. Husdan. 1965. Metabolic studies in prolonged fasting. II. Organic metabolism. Metab. (Clin. Exp.). 14: 47.

15. Sabeh, G., R. A. Alley, T. J. Robbins, J. V. Narduzzi, F. M. Kenney, and T. S. Danowski. 1969. Adrenocortical indices during fasting and obesity. J. Clin. Endocrinol. Metab. 29: 373.

16. Goodlad, G. A. J., and H. N. Munro. 1959. Diet and the action of cortisone on protein metabolism. Biochem. J. $73: 343$.

17. Wagle, S. R. 1966. Effects of insulin deficiency and cortisol administration on mobilization of protein to gluconeogenesis. Proc. Soc. Exp. Biol. Med. 121: 1297.

18. Ashmore, J., and D. Morgan. 1967. Metabolic effects of adrenal glucocorticoid hormones. Carbohydrate, protein, lipid, and nucleic acid metabolism. In The Adrenal Cortex. A. B. Eisenstein, editor. Little, Brown \& Co., Inc., Boston, Mass. 249.

19. Wool, I. G., and E. I. Weinshalbaum. 1959. Incorporation of $\mathrm{C}^{14}$-amino acids into protein of isolated diaphragms: role of the adrenal steroids. Am. J. Physiol. $197: 1089$.

20. Wool, I. G., and E. I. Weinshalbaum. 1960. Corticosteroids and incorporation of $\mathrm{C}^{14}$-phenylalanine into protein of isolated rat diaphragm. Am. J. Physiol. 198: 1111 .

21. Weinshalbaum, E. I., and I. G. Wool. 1961. Effect of adrenalectomy and corticosteroids on distribution of radioactivity in protein of cell fractions from myocardial slices. Nature (Lond.). 191: 1401.

22. Reiss, E., and D. Kipnis. 1959. The mechanism of action of growth hormone and hydrocortisone on protein synthesis in striated muscle. J. Lab. Clin. Med. 54: 937.

23. Kline, D. L. 1949. A procedure for the study of factors which affect the nitrogen metabolism of isolated tissues: hormonal influences. Endocrinology. 45: 596.

24. Rosen, F. 1963. Enzymes in tissues responsive to corticosteroids. Cancer Res. 23 : 1447.

25. Landau, B. R. 1965. Adrenal steroid and carbohydrate metabolism. Vitam. Horm. 23: 1 .

26. Kenney, F. T. 1970. Hormonal regulation of synthesis of liver enzymes. Mammalian Protein Metab. 4: 131. 
27. Albright, F. 1942-43. Cushing's syndrome. Harvey Lect. 38: 123.

28. Parson, W., K. R. Crispell, and A. Ebbert, Jr. 1952. Abnormalities in $\mathrm{N}^{16}$ excretion rates after ingestion of tagged glycine in Cushing's syndrome and following ACTH administration. J. Clin. Invest. 31: 548.

29. Eliel, L. P., and R. P. Heaney. 1954. Effect of variations in amino acid intake and protein deficit on the metabolic response of soft tissues and bone to cortisone acetate. J. Clin. Invest. 33: 930.

30. Lusk, G. 1928. The Elements of the Science of Nutrition. W. B. Saunders Company, Philadephia, Pa. 9th edition. 75.

31. Kaplan, S. A., and C. S. N. Shimizu. 1963. Effects of cortisol on amino acids in skeletal muscle and plasma. Endocrinology. $72: 267$.

32. Bondy, P. B. 1949. The effect of the adrenal and thyroid glands upon the rise of plasma amino acids in the eviscerated rat. Endocrinology. 45: 605.

33. Friedberg, F., and D. M. Greenberg. 1947. Endocrine regulation of amino acid levels in blood and tissues. $J$. Biol. Chem. 168: 405.

34. Lotspeich, W. D. 1950. Relations between insulin and pituitary hormones in amino acid metabolism. J. Biol. Chem. 185: 221.

35. Soupart, P. 1962. Free amino acids of blood and urine in the human. In Amino Acid Pools. J. T. Holden, editor. Elsevier, N. V. Uitgeuers Mij., Amsterdam. 220.

36. Ryan, W. L., and M. J. Carver. 1963. Immediate and prolonged effects of hydrocortisone on the free amino acids of rat skeletal muscle. Proc. Soc. Exp. Biol. Med. 114: 816 .

37. Smith, O. K., and C. N. H. Long. 1967. Effect of cortisol on the plasma amino nitrogen of eviscerated adrenalectomized-diabetic rats. Endocrinology. 80: 561.

38. Pozefsky, T., P. Felig, and J. S. Soeldner. 1968. Insulin blockade of amino acid release by human forearm tissues. Trans. Assoc. Am. Physicians Phila. 81: 258.

39. Zinneman, H. H., J. J. Johnson, and U. S. Seal. 1963. Effect of short-term therapy with cortisol on the urinary excretion of free amino acids. J. Clin. Endocrinol. Metab. 23: 996.

40. Long, C. N. H., B. Katzin, and E. G. Fry. 1940. The adrenal cortex and carbohydrate metabolism. Endocrinology. 26: 309.

41. Thorn, G. W., G. F. Koepf, R. A. Lewis, and E. F. Olsen. 1940. Carbohydrate metabolism in Addison's disease. J. Clin. Invest. 19: 813.

42. Randle, P. J., and H. E. Morgan. 1962. Regulation of glucose uptake by muscle. Vitam. Horm. 20: 199.

43. Munck, A. 1971. Glucocorticoid inhibition of glucose uptake by peripheral tissues: old and new evidence, molecular mechanisms, and physiological significance. Perspect. Biol. Med. 14: 265.

44. Owen, O. E., and G. A. Reichard, Jr. 1971. Human forearm metabolism during progressive starvation. $J$. Clin. Invest. 50: 1536.
45. Paul, P., and W. M. Bortz. 1969. Turnover and oxidation of plasma glucose in lean and obese humans. $M e-$ tab. (Clin. Exp.). 18: 570.

46. Shafrir, E., and D. Steinberg. 1960. The essential role of the adrenal cortex in the response of plasma free fatty acids, cholesterol, and phospholipids to epinephrine injection. J. Clin. Invest. 39: 310.

47. Havel, R. J., and A. Goldfien. 1959. The role of the sympathetic nervous system in the metabolism of free fatty acids. J. Lipid Res. 1: 102.

48. Goodman, H. M., and E. Knobil. 1961. Some endocrine factors in regulation of fatty acid mobilization during fasting. Am. J. Physiol. 201: 1.

49. Fain, J. N. 1962. Effects of dexamethasone and growth hormone on fatty acid mobilization and glucose utilization in adrenalectomized rats. Endocrinology. 71: 633.

50. Fain, J. N., R. O. Scow, and S. S. Chernick. 1963. Effects of glucocorticoids on metabolism of adipose tissue in vitro. J. Biol. Chem. 238: 54 .

51. Nayak, R. V., E. B. Feldman, and A. C. Carter. 1962. Adipokinetic effect of intravenous cortisol in human subjects. Proc. Soc. Exp. Biol. Med. 111: 682.

52. Dreiling, D. A., E. L. Bierman, A. F. Debons, P. Elsbach, and I. L. Schwarz. 1962. Effect of ACTH, hydrocortisone and glucagon on plasma nonesterified fatty acid concentration (NEFA) in normal subjects and in patients with liver disease. Metab. (Clin. Exp.). 11: 572 .

53. Reshef, L., and B. Shapiro. 1960. Effect of epinephrine, cortisone and growth hormone on release of unesterified fatty acids by adipose tissue in vitro. Metab. (Clin. Exp.). 9: 551.

54. Zierler, K. L., and D. Rabinowitz. 1963. Roles of insulin and growth hormone, based on studies of forearm metabolism in man. Medicine (Baltimore). 42: 385.

55. Fain, J. N., V. P. Kovacev, and R. O. Scow. 1966 Antilipolytic effect of insulin in isolated fat cells of the rat. Endocrinology. 78: 773.

56. Conn, J. W., and S. S. Fajans. 1956. Influence of adrenal cortisal steroids on carbohydrate metabolism in man. Metab. (Clin. Exp.). 5: 114.

57. Baird, I. M., and D. S. Munro. 1954. Addison's disease with diabetes mellitus. Lancet. 1: 962.

58. Thorn, G. W., A. E. Renold, and A. L. Winegrad. 1957. Some effects of adrenal cortical steroids on intermediary metabolism. Br. Med. J. 2: 1009.

59. Kinsell, L. W., S. Margen, G. D. Michaels, R. Reiss, R. Frantz, and J. Carbone. 1951. Studies in fat metabolism. III. The effect of ACTH, of cortisone, and of other steroid compounds upon fasting-induced hyperketonemia and ketonuria. J. Clin. Invest. 30: 1491.

60. Scott, J. L., Jr., and F. L. Engel. 1953. The influence of the adrenal cortex and cold stress on fasting ketosis in the rat. Endocrinology. 53: 410 .

61. Bieberdorf, F. A., S. S. Chernick, and R. O. Scow. 1970. Effect of insulin and acute diabetes on plasma FFA and ketone bodies in the fasting rat. J. Clin. Invest. $49: 1685$. 